\title{
Tobacco Leaf Protein: II. Genetic and Fractionation Approaches to Improving Tobacco Leaf Protein Production*
}

\author{
Donald W. De Jong and George Pittarelli \\ United States Department of Agriculture, Agricultural Research Service, \\ Crops Research Laboratory, Oxford, North Carolina and \\ United States Department of Agriculture, Agricultural Research Service \\ Beltsville Agricultural Research Center, Beltsville, Maryland, U.S.A.***
}

\section{SUMMARY}

Tobacco variety T.I. 401 was evaluated for seasonal leaf protein yields and crossbred with other genotypes to determine whether leaf protein yield was a genetically transmissible trait. Relatively high leaf protein yields associated with later maturity were observed in preliminary trials but additional crossbreeding and selection is deemed necessary to achieve stable integration of improved leaf protein yields and desirable agronomic performance. Chromatographic and electrophoretic analyses demonstrated that high leaf protein yield of T.I. 401 was not associated with a particular protein fraction but rather was a general phenomenon affecting all major protein classes. Besides examining genetic factors for improving leaf protein yields, two mechanical improvements in leaf protein fractionation technology were introduced into the process. A mild acidification step (to $\mathrm{pH}$ 5.5) with a subsequent moderate heat treatment $\left(50^{\circ} \mathrm{C}\right)$ resulted in a green coagulum which was readily removed by brief low speed centrifugation without substantial loss of the fraction containing soluble protein which precipitates as a white pellet when heated to $80^{\circ} \mathrm{C}$. Hollowfiber membrane technology was also investigated as a means of producing a purified concentrate with high levels of undegraded protein. The membrane system tested was relatively efficient and greatly improved the quality of the protein product.

\footnotetext{
Received: 27th March 1989 - accepted: 27th June 1989.

$*$ The work reported here was conducted while the authors were with the Tobacco Laboratory, Beltsville Agriculture Research Center.
}

\section{ZUSAMMENFASSUNG}

Die Tabak-Varietät T.I. 401 wurde auf ihren jahreszeitlich unterschiedlichen Blattproteingehalt untersucht und mit anderen Genotypen gekreuzt, um festzustellen, ob der Proteingehalt ein genetisch vererbbares Merkmal ist. In Vorversuchen wurde ein relativ hoher, mit der späteren Reife der Pflanze assoziierter Proteingehalt beobachtet; zusätzliche Kreuzungszüchtung und Selektion werden jedoch als notwendig erachtet, um einen erhöhten Blattproteingehalt zu sichern und um für die Landwirtschaft wünschenswerte Ergebnisse zu gewährleisten. Chromatographische und elektrophoretische Analysen zeigten, daß ein hoher Gehalt an Blattprotein der Varietät T.I. 401 nicht nur in einer bestimmten Proteinfraktion vorkam, sondern es sich vielmehr um ein allgemeines Phänomen handelte, das sich auf alle wichtigen Proteinklassen bezog. Neben der Untersuchung genetischer Faktoren zur Verbesserung der Proteinerträge aus dem Blattgut wurden zwei neue Techniken zur Fraktionierung von Blattprotein eingeführt. Eine milde Ansäuerung (bis auf $\mathrm{pH} 5,5)$ mit nachfolgender leichter Erwärmung $\left(50^{\circ} \mathrm{C}\right)$ führte zu einem grünen Koagulat, welches problemlos durch kurzes, langsames Zentrifugieren entfernt werden konnte, ohne zu bedeutenden Substanzverlusten bei der löslichen Proteinfraktion zu führen, welche erst bei Erhitzung auf $80^{\circ} \mathrm{C}$ als weißes Pellet ausfällt. Zur Herstellung eines gereinigten Konzentrats mit einem hohen Anteil an nicht denaturiertem Protein wurde die Hohlfasermembrantechnik erprobt. Das untersuchte Membransystem war recht wirksam und führte zu einer wesentlichen Verbesserung der Qualität des Proteins. 


\section{RESUME}

On a analysé les variations saisonnières des teneurs en protéines foliaires dans la variété de tabac T.I. 401 et croisé cette variété avec d'autres génotypes pour déterminer si la teneur en protéines foliaires était une caractéristique génétique. Des essais préliminaires ont rendu comte des teneurs élevées en protéines foliaires associées à une maturité retardée, mais l'hybridation et la sélection étaient jugées nécessaire pour arriver à une intégration stable de la teneur augmentée en protéines foliaires et pour assurer des performances agronomiques désirables. Des analyses chromatographiques et électrophorétiques ont révélé que la teneur élevée en protéines foliaire dans T.I. 401 n'était pas associée à une fraction protéique particulière mais qu'il s'agissait plutôt d'un phénomène général qui se rapportait à toutes les classes protéiques importantes. Outre l'examen des effets de facteurs génétiques sur la teneur en protéines foliaires, deux techniques améliorées ont été introduites dans le processus de fractionnement du contenu protéique des feuilles. L'acidification légère (jusqu'à $\mathrm{pH} 5.5$ ) et le réchauffement modéré à $50^{\circ} \mathrm{C}$ ont fourni un coagulum vert qui était facilement éliminé par une courte centrifugation à vitesse modérée, ceci sans entraîner la perte des protéines solubles. Celles-ci précipitent sous forme de culot après réchauffement à $80^{\circ} \mathrm{C}$. La filtration sur membrane en fibre creuses a été utilisée pour obtenir un concentré protéique purifié contenant un taux élevé en protéines dénaturés. Le système de filtre moléculaire testé était relativement efficace et apportait une amélioration de la qualité protéique.

\section{INTRODUCTION}

In the companion paper (see this volume), the use of putative chemical growth regulators as foliar sprays to improve tobacco leaf protein yield in an extraction process was reported. During the course of that investigation, T.I. 401 was found to exhibit certain traits that were associated with high leaf protein yields. Although consistently a high leaf protein producer, T.I. 401 displayed serveral undesirable agronomic features. Early and profuse sucker development is characteristic of primitive tobacco types (1). Interest in T.I. 401 was originally motivated by its reportedly high nicotine content (2). However, after surveying both high and low alkaloid types we concluded that there was no general association between nicotine and protein content.

The principal objective of the breeding experiments was to ascertain whether the high leaf protein trait of T. I. 401 could be exploited while modifying its less desirable agronomic properties. As part of the investigation, the nature of the specific protein components that contributed to higher protein levels in the leaf extracts was explored by a combination of chromatographic and electrophoretic methods. In addition, two ancillary techniques for improving the protein fractionation operation are described. It was previously shown (3) that both the amount and quality of the protein product depends upon the type of treatment used to take out the green fraction. The first of these innovations was the development of a two-step sequential procedure for selectively destabilizing the green fraction so that it coagulated. The primary goal was to permit the use of low speed centrifugation to obtain a clarified extract containing a maximum amount of the soluble protein fraction freed from chlorophyll associated protein. A second methodology involved the use of a semi-preparative hollow fiber membrane unit to remove non-protein contaminates by ultrafiltration while concentrating the protein component by diafiltration prior to precipitation.

Examination of leaf protein yields obtained from reciprocal hybrids and selected backcrosses indicated that the superior leaf protein yielding trait was amenable to genetic selection by classical plant breeding methods. Although the profiles often showed minor deviations, the mobilities of major protein classes observed on electrophoregrams and chromatograms were generally quite similar.

\section{EXPERIMENTAL}

\section{Plant Material}

Several varieties of Nicotiana tabacum including the popular Maryland type cultivar, MD 609, were used in these studies. In addition, three genotypes from the Tobacco Introductions collection were utilized for breeding work. Progenies of T. I. 401 hybridized with T. I. 516 and T.I. 560 were grown in greenhouse and field to evaluate growth habit and protein production properties. Figure 1 shows field plots of T.I. 516 and T.I. 401 growing side-by-side to demonstrate their contrasting growth habits. Reciprocal crosses between T.I. 401 and T.I. 516 were selected for backcrossing. In all cases, the principal objective was to determine the leaf protein extraction potential of the hybrids compared to the parental varieties.

\section{Preparation of Protein Extracts}

For field-grown plants, the extraction protocol employed was similar to that described elsewhere (3). Whole leaves were customarily macerated in an extrusion grinder with addition of $600 \mathrm{mg}$ of $\mathrm{NaOH}$ and $3 \mathrm{~g}$ of sodium metabisulfite per $\mathrm{kg}$ of leaf material. Juice was separated from fiber by filtration through a nylon bag with a Norwalk ram press*. In the initial work, two methods for removal of the green fraction were compared - one involving acidification to $\mathrm{pH} 5.0$ with citric acid and the other heating of the green juice to $50^{\circ} \mathrm{C}$ followed by centrifugation. It was found that the soluble protein in some of the samples was unstable below $\mathrm{pH} 5.5$ resulting in lower recoveries of the white protein fractions. Therefore, a new technique was adopted that combined both $\mathrm{pH}$ adjustment and low heat. The protocol for this 
Figure 1.

Row plots of T. I. 515 (left) and T. I. 401 (right) growing in the field at the Beltsville Agriculturall Research Center. Note that T. I. 401 is in full flower and suckering whereas T. I. 516 is entirely vegetative. The plants are readily distinguishable as to leaf size/shape and growth habit.

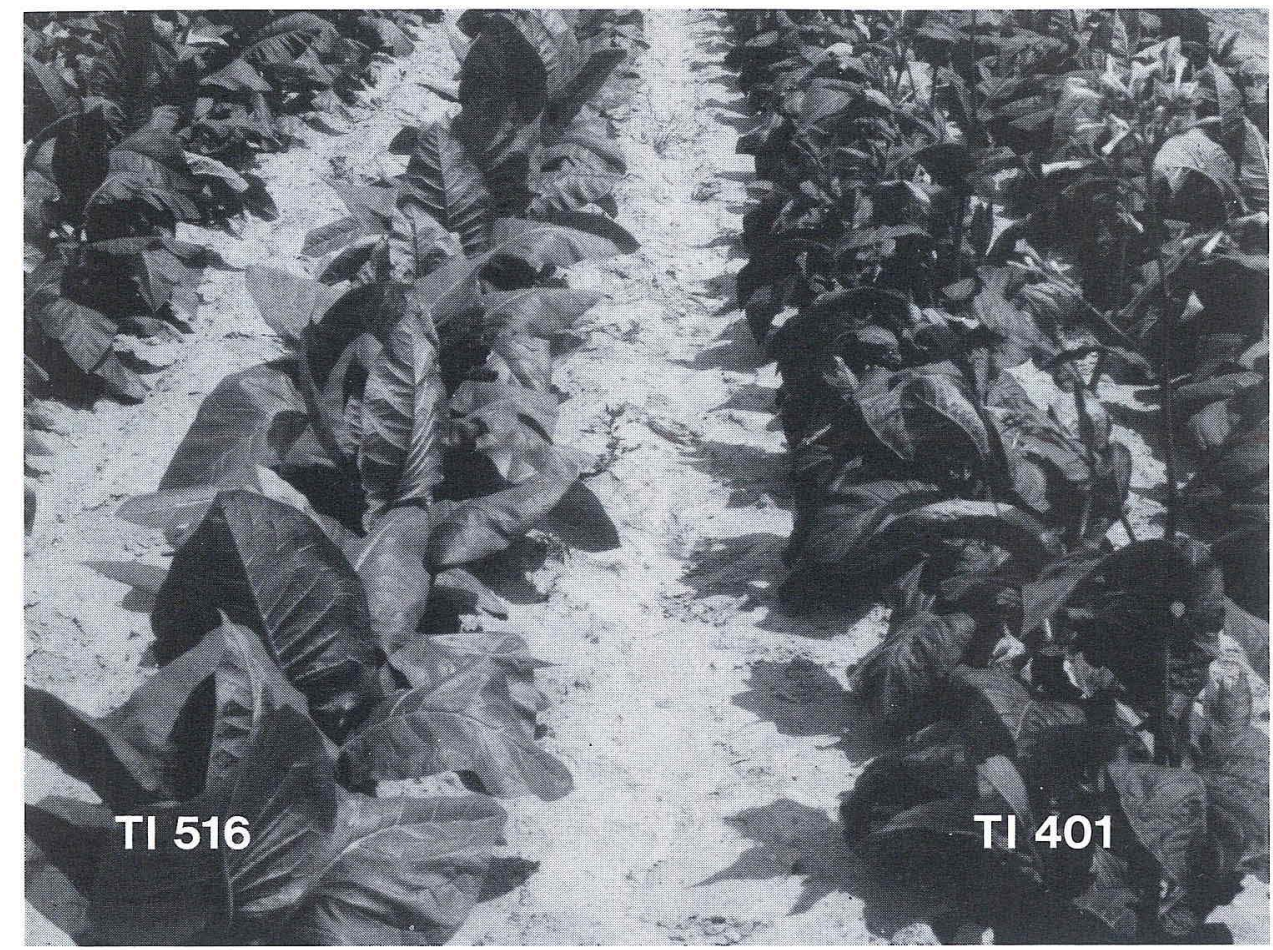

method is shown on the flow-chart in Figure 2. This twostep operation successfully removed the green fraction from leaf samples regardless of source leaving substantial amounts of protein in solution to be removed later by an $80^{\circ} \mathrm{C}$ treatment. The soluble protein fraction was measured in the clarified extracts with the Bradford dye reagent obtained from either Biorad or Pierce Chemical Company* (4).

No attempt was made in these studies to separate Fraction I and Fraction II proteins $(5,6)$. When large numbers of greenhouse-grown plants were to be screened, the amount of leaf material was reduced from $1 \mathrm{~kg}$ to $100 \mathrm{~g}$ and $\mathrm{NaOH}$ and sodium metabisulfite were applied by spraying a concentrated solution on the leaves as they were fed into a small hand-operated extrusion mill. In order to test the stability of soluble protein during additional processing a Romicon hollow-fiber membrane module (Model HF-LAB-1 EX with 30000 M.W. cutoff) was utilized. One liter of brown juice was passed through the hollow-fiber system in recirculation mode and the retentate sampled to determine the amount and composition of protein in the concentrated juice.

\footnotetext{
Mention of a trademark or proprietary product does not constitute a guarantee or warranty of the product by the U.S. Department of Agriculture and does not imply its approval to the exclusion of other products that may also be suitable.
}

\section{Analyses of Protein Components}

Chromatography and electrophoresis were used to differentiate proteins in the clarified extracts. The chromatographic system employed was a Fast Protein Liquid Chromatography (FPLC) instrument (LkB/Pharmacia) using a Mono-Q anion exchange column. Prior to injection on the FPLC system, $10 \mathrm{ml}$ portions of the extract were eluted with deionized water by gravity flow through a $360 \times 10 \mathrm{~mm}$ Sephadex G-50 column in order to eliminate non-protein interferences. A $500 \mu$ l sample of the first $10 \mathrm{ml}$ fraction eluting after the void volume was injected onto the Mono-Q column and eluted with a step gradient of $0.5 \mathrm{M} \mathrm{NaCl}$ in $0.02 \mathrm{M}$ Tris-HC1 buffer $(\mathrm{pH}$ 8.0). The program was set for 20 minutes and run at a flow rate of $1.0 \mathrm{ml} / \mathrm{min}$. Peak detection was monitored at both $254 \mathrm{~nm}$ and $280 \mathrm{~nm}$ absorbance and fractions were collected for subsequent electrophoretic separations. Peak heights and integrated values for peak areas were recorded from data automatically calculated by the FRAC-100 fraction collector.

A vertical slab gel format $(200 \mathrm{~cm} \times 130 \mathrm{~cm} \times 0.75 \mathrm{~mm}$, obtained from American BioNuclear, Inc.) was used for one dimensional electrophoresis. Samples were routinely separated on a $7.5 \%$ polyacrylamide non-denaturing gel system, stained with Coomassie Blue G-250 and then photographed in color. In addition, samples were occasionally analyzed for polypeptides with a sodium dodecyl 
Figure 2.

Flow-chart of protein fractionation process described in this paper. Ancillary experiments were also conducted with the fiber residue but are not included here. The tan protein pellet is off-white in color frequently referred to as "white" protein.

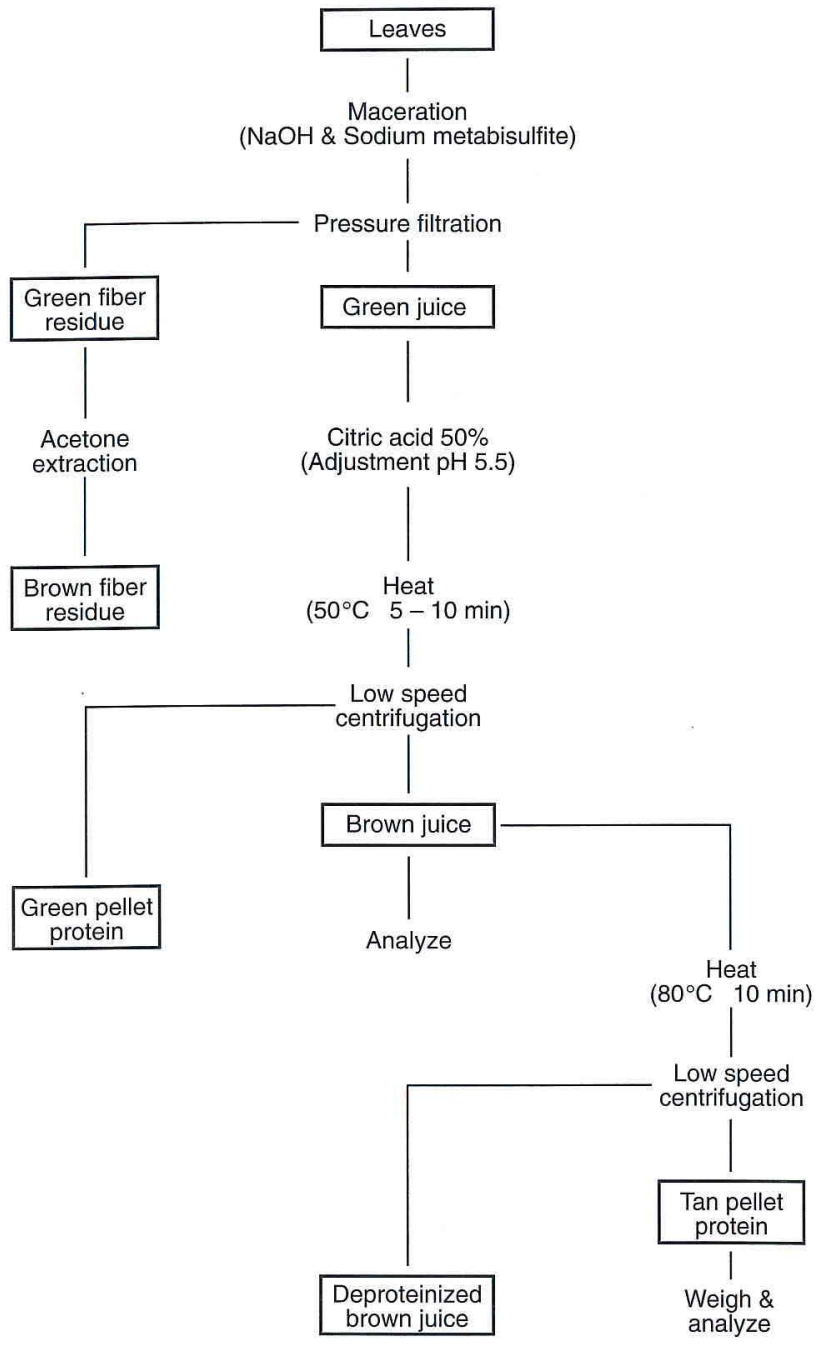

sulfate (denaturing) gel system. Stained bands were quantified with a Lвк laser densitometer.

\section{RESULTS}

\section{Extraction and Fractionation}

Moderate acidification or alternatively mild heat treatment have been used previously to destabilize the green fraction in leaf extracts as a means of clarifying the soluble protein fraction for subsequent analysis and/or manipulation. Although more soluble protein was retained after heating to $50^{\circ} \mathrm{C}$ than following acidification, prolonged high speed centrifugation was required to remove the coagulated green fraction from heat treated extracts. Unfortunately, adjustment of $\mathrm{pH}$ to at least 5.0 was needed with most samples to totally eliminate the green fraction. Some samples, depending upon plant type or stage of plant development, lost successively greater amounts of soluble protein as the extract was progressively acidified. This is shown in Table 1 where three tobacco genotypes are compared. As the $\mathrm{pH}$ was shifted downward from a starting point of 5.6, the concentration of protein in the extract decreased as more and more soluble protein was lost with the green pellet. This is particulary noticeable with T.I. 401 where the protein retained in solution dropped from $5.9 \mathrm{mg} / \mathrm{ml}$ to $1.34 \mathrm{mg} /$ $\mathrm{ml}$. The soluble protein in T. I. 516 appeared to be more stable and only dropped from $4.20 \mathrm{mg} / \mathrm{ml}$ to $3.14 \mathrm{mg} / \mathrm{ml}$. Incidentally, although leaf extracts of T.I. 516 and T.I. 560 were still opaque and green at $\mathrm{pH}$ 5.6, extracts from T.I. 401 were clear. We subsequently found that by adjusting the $\mathrm{pH}$ to 5.5 with citric acid and then heating briefly to $50^{\circ} \mathrm{C}$ in a water bath, essentially all of the soluble protein was retained and removal of the green fractions was easily accomplished by a short, low speed centrifugation step $(3000 \times \mathrm{g}$ for 5 minutes). The soluble protein fraction was quickly heat precipitated by dipping into a water bath at $80^{\circ} \mathrm{C}$ and dried for subsequent analysis. The procedure was found to be very reliable for comparing soluble protein levels in leaf samples from diverse maturities and different germplasm backgrounds.

Table 1.

Protein content of brown juice extract.

\begin{tabular}{c|c|c|c}
\hline Effect of pH adjustment prior to $50^{\circ} \mathrm{C}$ heat treatment \\
\hline \multirow{2}{*}{$\mathrm{pH}$} & \multicolumn{3}{|c}{$\begin{array}{c}\text { Varietal Comparisons } \\
\text { *Potein (mg/ml) }\end{array}$} \\
\cline { 2 - 4 } & T.I. 401 & T.I. 516 & T.I. 560 \\
\hline 5.60 & 5.90 & 4.20 & 3.55 \\
5.45 & 4.37 & 3.60 & 3.17 \\
5.35 & 4.10 & 3.41 & 2.02 \\
5.20 & 1.34 & 3.14 & 0.91 \\
\hline
\end{tabular}

*Bradford Dye Assay.

\section{Genotype Hybridization and Selection}

As reported in our companion paper (3), leaf extracts from tobacco variety, T.I. 401, from the Tobacco Introductions collection showed consistently high levels of leaf protein throughout the growing season. Compared with cultivar MD 609, the leaf protein content in T. I. 401 even exhibited a tendency to increase slightly during plant maturity instead of decreasing after flower formation which is typical of all the other plant varieties we have examined to date (Figure 3). Since T. I. 401 is characterized by some undesirable agronomic traits (Figure 4), a plant breeding progam was initiated to determine to what extent these could be modified by crossbreeding T. I. 401 with T.I. 516, T.I. 560 and MD 609 without losing the high leaf protein content. T. I. 516 was especially suited for this objective because a number of its properties contrasted sharply with those of T. I. 401. T. I. 516, which is classified as a cigar type, matures late, has a robust habit 
Figure 3.

Tobacco leaf protein extraction. Comparison of changes in amounts of extractable "white" protein between T. I. 401 and a typical Maryland cultivar, MD 609, during the growing season. Sampling with T.I. 401 commenced earlier because this genotype matures more rapidly. Note the relatively stable levels of leaf protein available from T. I. 401 in contrast to MD 609 which show a steady decline during maturation.

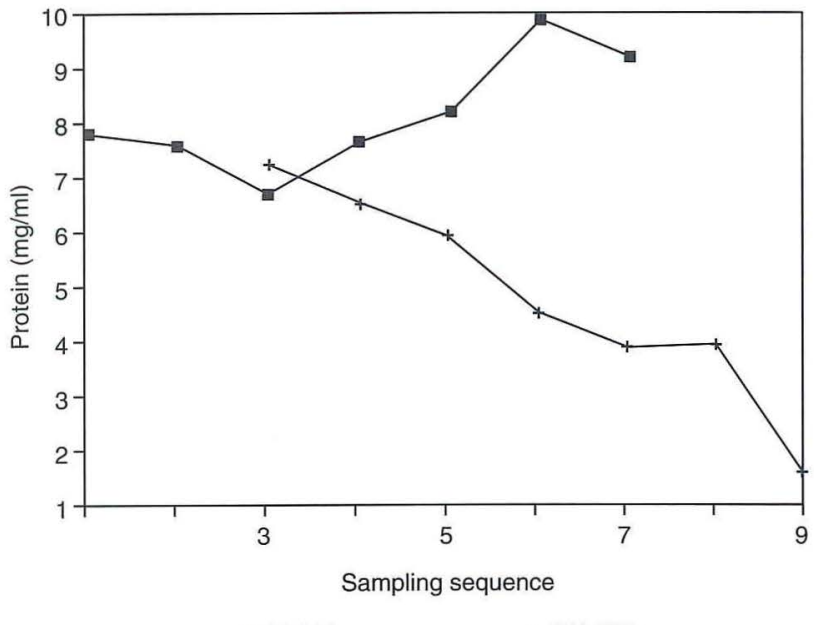

- Tl $401+$ MD 609

and large attractive leaves. Most of the work reported in this paper summarizes hybridization experiments with T. I. 401 and T. I. 516. During initial greenhouse trials it appeared that with T.I. 401 as the paternal parent, the resulting hybrids produced higher leaf protein levels than the reciprocal cross with T.I. 516. As shown in Table 2, the highest leaf protein value was obtained from hybrids from the cross T. I. $516 \times$ T. I. 401 with a mean of $3.37 \mathrm{mg} /$ $\mathrm{ml}$ compared to a mean of $2.67 \mathrm{mg} / \mathrm{ml}$ for the reciprocal hybrids. This study also suggested that extraction before noon yielded more leaf protein than extraction in the afternoon. It should be emphasized that the protein concentrations shown in this table are somewhat lower than those obtained from comparable field-grown plants as will become apparent in the sequel. Because of the wide
Figure 4.

T.I. 401 traits pertinent to protein recovery. Table showing favorable and unfavorable genetic traits of T. I. 401 with respect to leaf protein recovery.

\begin{tabular}{c|c}
\hline Favorable & Unfavorable \\
\hline $\begin{array}{l}\text { 1. High leaf protein } \\
\text { accumulation }\end{array}$ & 1. Small plant \& leaves \\
$\begin{array}{l}\text { 2. Extended protein } \\
\text { retention period }\end{array}$ & $\begin{array}{l}\text { 2. Excessive branching } \\
\text { habit }\end{array}$ \\
$\begin{array}{l}\text { 3. Ease of protein } \\
\text { fractionation }\end{array}$ & 3. Early flowering behavior \\
\hline
\end{tabular}

difference in maturity rates of the parental genotypes, hybrid plants were harvested in field trials that were judged to be in early, mid or late stages of flowering. For the cross T. I. $516 \times$ T. I. 401 , with T. I. 401 as the paternal parent, there was less difference in leaf protein levels early in the season whether the plant was in full flower or not, than later in the season, when plants that were beginning to flower were compared to plants that were in full flower (Table 3). These data appear to indicate that the T.I. 401

Table 2.

Performance of tobacco hybrids for leaf protein extraction.

\begin{tabular}{l|c|c}
\hline \multicolumn{3}{c}{$\begin{array}{c}\text { Reciprocal crosses* } \\
\text { Protein }(\mathrm{mg} / \mathrm{ml})\end{array}$} \\
\hline & T.I. $516 \times$ T.I. 401 & T.I. $401 \times$ T.I. 516 \\
\hline $\bar{X}$ & AM & AM \\
S.E. & $3.37 \pm 0.96 \mathrm{a}^{* *}$ & $2.67 \pm 0.39 \mathrm{~b}$ \\
& 0.25 & 0.10 \\
$\bar{X}$ & $\mathrm{PM}$ & $\mathrm{PM}$ \\
S.E. & $2.73 \pm 0.62 \mathrm{~b}$ & $2.48 \pm 0.30 \mathrm{~b}$ \\
\hline
\end{tabular}

* Under comparable conditions T.l. 401 parent yielded $4.37 \mathrm{mg} / \mathrm{ml}$ and T.I. 516 yielded $2.60 \mathrm{mg} / \mathrm{ml}$.

** Means having common letters within a row or column are not significantly different at the 0.05 level of probability based on the t-test $\mathrm{N}=15$ for each of the four plots.

Greenhouse trial.

Table 3.

Tobacco leaf protein extraction

\begin{tabular}{|c|c|c|c|c|}
\hline \multirow[t]{2}{*}{ Date } & \multicolumn{3}{|c|}{$\begin{array}{c}\text { T.I. } 516 \times \text { T.I. } 401(\mathrm{~F} 1)=\# 465 \\
\text { Protein }(\mathrm{mg} / \mathrm{ml}) \\
\text { Flower stage }\end{array}$} & \multirow[b]{2}{*}{$\bar{x}$} \\
\hline & Early & Mid & Late & \\
\hline $7 / 25$ & 4.04 & 4.98 & 5.18 & $4.73 \pm 0.61 \mathrm{~d}^{*}$ \\
\hline $7 / 30$ & 2.05 & 4.04 & 4.13 & $3.41 \pm 1.18 d$ \\
\hline $8 / 01$ & 2.36 & 4.18 & 2.02 & $2.85 \pm 1.16 \mathrm{~d}$ \\
\hline $8 / 06$ & 2.58 & 4.25 & 5.01 & $3.94 \pm 1.24 d$ \\
\hline $\bar{x}$ & $2.76 \pm 0.88 a^{*}$ & $4.36 \pm 0.42 b c$ & $4.08 \pm 1.45 \mathrm{ac}$ & \\
\hline
\end{tabular}

* Means having common letters within a row or a colums are not significantly different at the 0.05 probability level based on the $t$-test. Field studies. 
trait for high leaf protein levels associated with full maturity can be transmitted to progeny in a breeding program. In other hybridization experiments, it was found that selected F1 hybrids backcrossed to T. I. 401 contained acceptable levels of leaf protein within the same range as selfed F2 plants (Table 4).

Table 4.

Tobacco leaf protein extraction.

\begin{tabular}{c|c|c|c}
\hline \multicolumn{4}{c}{ T.I. $401 \times$ T.I. 516 } \\
\hline $\begin{array}{c}\text { Selection } \\
\text { X1 401 BC }\end{array}$ & $\begin{array}{c}\text { Protein } \\
(\mathrm{mg} / \mathrm{ml})\end{array}$ & $\begin{array}{c}\text { Selection } \\
\text { F2 Selfed }\end{array}$ & $\begin{array}{c}\text { Protein } \\
(\mathrm{mg} / \mathrm{ml})\end{array}$ \\
\hline$\# 16-1$ & 6.63 & $\# 100-1$ & 6.39 \\
$\# 16-2$ & 6.59 & $\# 100-2$ & 6.23 \\
$\# 16-3$ & 5.96 & $\# 100-2$ & 6.47 \\
Mean & 6.39 & & 6.36 \\
S.D. & \pm 0.38 & & \pm 0.12 \\
\hline
\end{tabular}

Field studies.

\section{Chromatographic Analyses}

During development of a suitable protocol for chromatographic analysis of the protein composition in clarified leaf extracts, it was found that a gel filtration step was required to remove the low molecular weight contaminants prior to sample injection in order to avoid spurious peaks on the chromatogram. After standardizing chromatographic conditions, analyses were run of several hundred leaf protein samples. In order to simplify

Table 5.

Fast protein liquid chromatography of tobacco leaf high molecular weight fraction.

\begin{tabular}{c|cccc}
\hline Zone & Peak & Retention time & Frequency \\
\hline A & 1 & 0.27 & 79.6 \\
& 2 & 1.23 & 38.8 \\
& 3 & 1.73 & 38.8 \\
& 4 & 2.05 & 14.3 \\
& 5 & 2.70 & 28.6 \\
\hline B & 1 & 5.28 & 16.3 \\
& 2 & 5.57 & $87.3^{*}$ \\
& 3 & 6.66 & 14.3 \\
& 4 & 7.10 & 18.4 \\
& 5 & 7.31 & 36.7 \\
& 6 & 7.61 & 36.7 \\
& 7 & 8.58 & 4.1 \\
\hline C & 1 & 9.77 & 10.2 \\
& 2 & 10.43 & $85.7^{*}$ \\
\hline \multirow{2}{*}{ D } & 1 & 13.73 & 8.2 \\
& 2 & 14.50 & 61.2 \\
Total & 17 & 15.40 & 28.6 \\
\cline { 2 - 4 } & 3 & & \\
\hline
\end{tabular}

* Most frequent occurrence. interpretation and comparison of chromatograms, the peaks were labelled according to one of four major mobility groups designated Zones A, B, C and D. A set of typical chromotograms is shown in Figure 5, illustrating the excellent resolution obtained with the FPLC system. The large peak in Zone $\mathrm{C}$ was identified as Fraction I (ribulose 1,5-bisphosphate carboxylase/oxygenase) or RuBisCo by solubility and electrophoretic behavioral properties. Peak integration of chromatograms showed that this component represented from $33 \%$ to $50 \%$ of the soluble protein in leaf extracts. The retention time (10.43 minutes) for this peak was consistent from one run to the next. The only other peak that exhibited no deviation was the one labelled B2 as shown in Figure 5 which had a retention time of 5.57 minutes.

Figure 5.

Representative FPLC chromatograms of gel filtered tobacco leaf extracts from T.I. genotypes and breeding lines. The arrows point to the two least variable peaks in the chromatographic separation. B-2 is an unknown relatively constant protein component, whereas $\mathrm{C}-2$ which has been identified as Fraction I, or RuBisCo (ribulose 1,5-biphosphate carboxylase/oxygenase), consists of up to $50 \%$ of the total soluble "white" protein fraction.
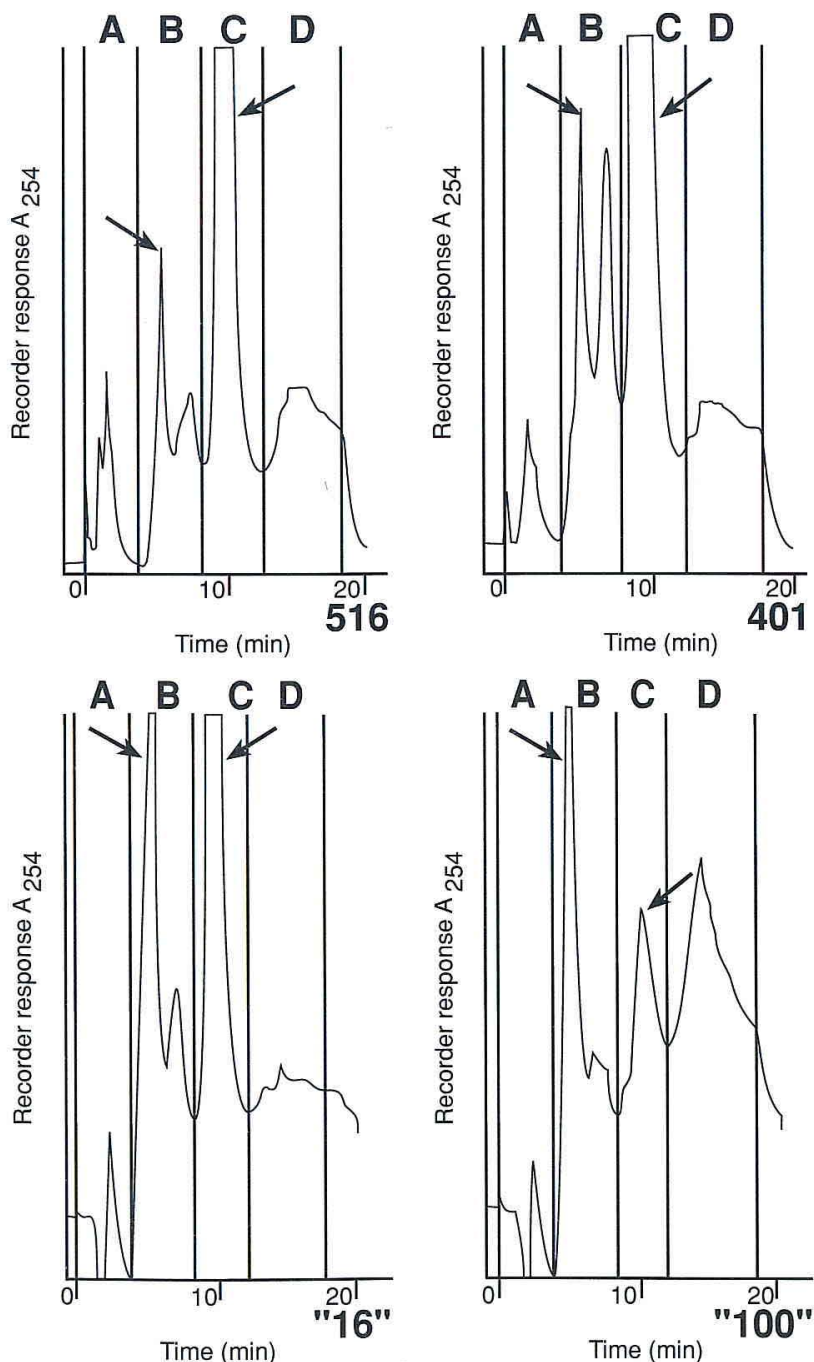
Figure 6.

Densitometer scan and computer-processed data on mobilities and relative abundance of polypeptides in tobacco leaf extracts separated by SDS-gel electrophoresis. Dot marks indicate positions of the large and small subunits of RuBisCo (ribulose 1,5-biphosphate carboxylase/oxygenase). This is a denaturing gel system. Staining was with Coomassie Blue.
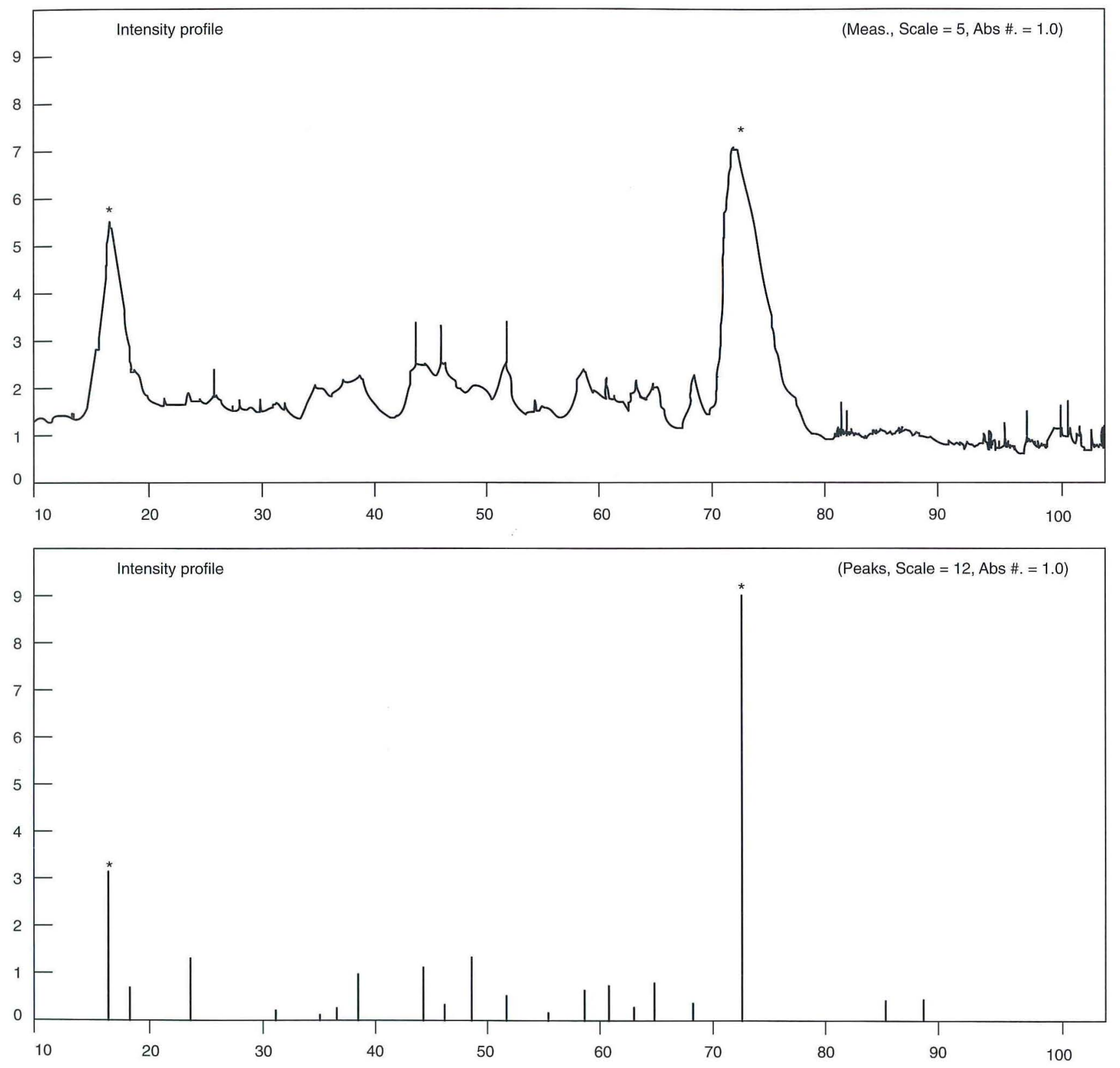

Intensity data $($ Scale $=12$, Abs\#. $=1.0)$

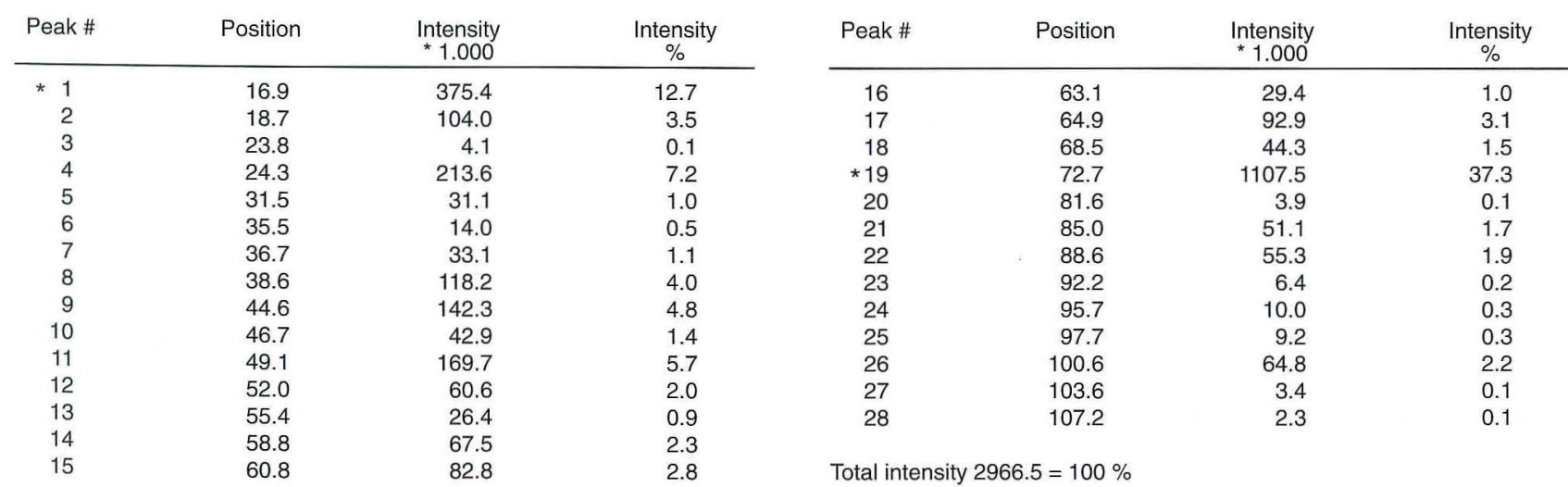


The 17 protein components that were identified as distinct chromatographic peaks are listed in Table 5. Approximately half of these were represented on any particular chromatogram with the other peaks either absent or overshadowed by an adjacent peak at higher concentration. Oftentimes a peak shoulder in one chromatogram appeared as a main peak in another chromatogram of a different sample. The precision from run to run of the same sample was very high - therefore, any peak height difference of more than $2 \%$ or a retention time difference of more than 0.25 minutes was regarded as a real difference. On only a couple of occasions was a major peak observed in Zone D and invariably this was associated with a reduced peak in the region of Zone C. A summary of the two most consistent peaks, B2 and C2 is given in Table 6. Although B2 is a major protein component representing between $8 \%$ and $16 \%$ of the total soluble protein in tobacco leaf extracts, its identity is unknown.

Table 6.

FPLC fractionation of major protein components.

\begin{tabular}{|c|c|c|c|c|}
\hline \multirow[b]{2}{*}{ Peak I.D. } & \multicolumn{4}{|c|}{ Entries } \\
\hline & $\begin{array}{l}M D \\
609\end{array}$ & $\begin{array}{l}\text { T.I. } \\
401\end{array}$ & $\begin{array}{c}\text { T.I. } \\
516\end{array}$ & $\begin{array}{l}\text { T.I. } \\
995\end{array}$ \\
\hline & \multicolumn{4}{|c|}{$\%$} \\
\hline B2 (Unknown) & $7.8^{*}$ & 9.6 & 8.9 & 16.0 \\
\hline C2 (Rubisco) & 33.5 & 49.3 & 40.6 & 41.9 \\
\hline
\end{tabular}

* Percent of Total Protein.

\section{Electrophoretic Analyses}

Results obtained with the denaturing gel system patterned after that of LAEMmLi (7) are illustrated in Figure 6. Computerized laser densitometry produces a graph and converts band mobilities and intensities into values that aid protein interpretation. One dimensional polyacrylamide gel electrophoresis is capable of distinguishing 28 major polypeptides in tobacco leaf extracts containing protein at concentrations between $2 \mathrm{mg} / \mathrm{ml}$ and $4 \mathrm{mg} / \mathrm{ml}$. The most prominent bands are the two subunits of Rubisco (Bands 1 and 19) which in the example shown comprised $50 \%$ of the total protein load based on integration values. Non-denaturing electrophoresis which lacks the detergent, sodium dodecyl sulfate, was used more frequently for routine analyses because proteins can be characterized in their native state. The representative electrophoregram in Figure 7 compares six samples extracted and analysed simultaneously. The banding pattern obtained with T.I. 401 extracts (Lane 4) was more heavily stained than the others reflecting higher protein levels, but no qualitative differences were detected. When individual chromatographic fractions were electrophoresed, several bands corresponding to the principal chromatographic peaks were identified. The most retarded band in the electrophoregram was found to be RuBisCo (C2), while the B2 fraction was found to be
Figure 7.

Electrophoregram of tobacco leaf extracts separated with a $7.5 \%$ nondenaturing gel. Samples were applied in the following order, from left to right, Lane $1=$ T. I. 516; Lane $2=$ T. I. 995, Lane $3=$ BL 16/465, Lane $4=$ T. I. 401, Lane $5=$ BL 16/465, Lane $6=$ BL 16/465. T.I. indicates Tobacco Introduction; BL indicates Breeding Line.

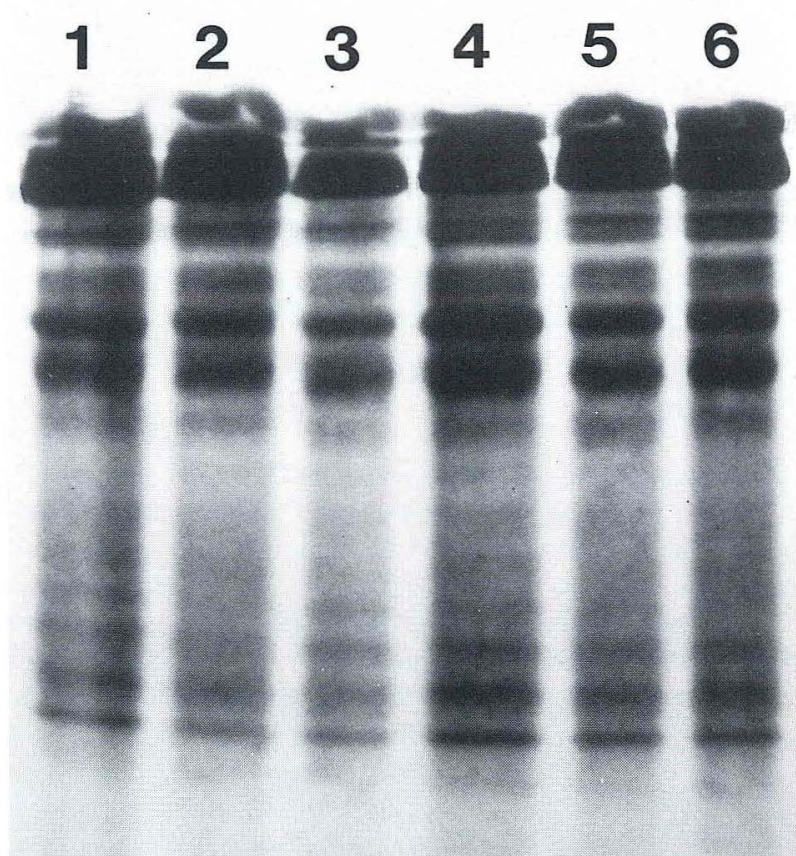

composed of two adjacent proteins which migrated as a pair of similar staining electrophoresis bands (Figure 8). These data confirmed the integrity of the protein components in the extraction procedure and provided a means for monitoring the fate of proteins during extraction and subsequent processing by ultrafiltration.

\section{Ultrafiltration of Protein Extracts}

A semi-preparative scale ultrafiltration unit was used to separate protein constituents from non-protein contaminants in tobacco leaf extracts. The graph in Figure 9 depicts changes in the rate of concentration during a typical 20 minutes run with a Romicon ultrafiltration apparatus operating in recirculation mode. Chemical analysis of the retentate revealed that the protein level had been increased from $2.93 \mathrm{mg} / \mathrm{ml}$ to $39.82 \mathrm{mg} / \mathrm{ml}$ with a fluid volume reduction of $85 \%$. Furthermore, the protein purity increased from approximately $70 \%$ to $93.13 \%$. No protein was detected in the permeate. Chromatographic analysis of the retentate (diluted 1:10 before injection) showed that little or no change in the protein profile had occurred, indicating that the hollow-fiber system did not appear to damage the structural conformation of individual proteins in the original extract. 
Figure 8.

Electrophoregram showing correlation between major electrophoretic bands and chromatographic peaks.

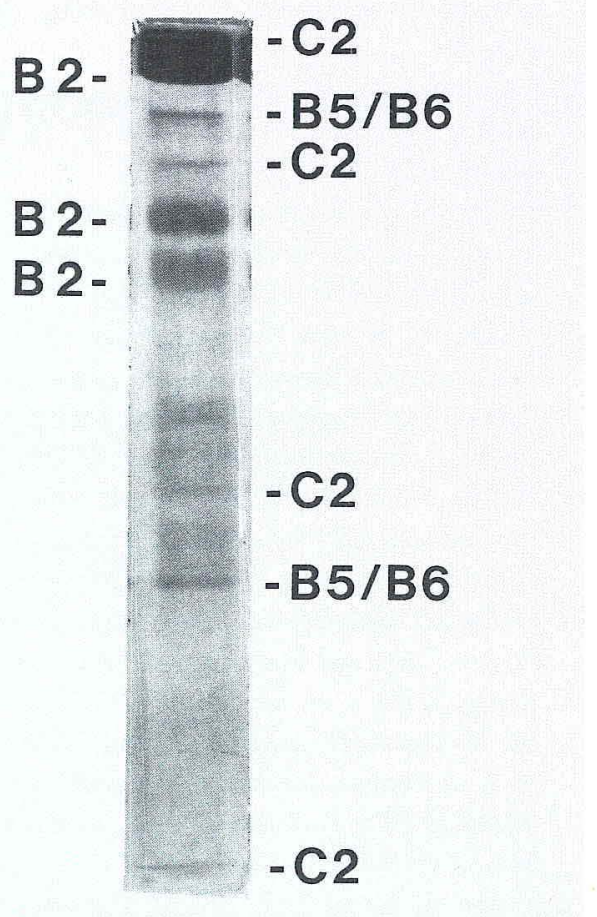

\section{DISCUSSION}

These results and those of others (8) clearly demonstrate that tobacco genotypes vary greatly in leaf protein content. It has also become apparent that existing commercial cultivars, i.e. flue-cured and Maryland types that have previously been investigated, are not suitable for leaf protein production. Only varieties that maintain soluble protein levels of $5 \mathrm{mg} / \mathrm{ml}$ or more throughout the growing season are useful for obtaining practical quantities of leaf protein. After conducting surveys of the T.I. collection for a number of seasons, we have concluded that there are two parameters that are important in leaf protein production from tobacco:

1. Consistently high leaf protein levels maintained throughout plant development.

2. Facile separation of the green protein fraction from the soluble protein fraction.

Although T. I. 401 is a good candidate with regard to both of these criteria, it is not an ideal commercial variety, because it displays primitive traits that make it a poor agronomic crop. The data indicate that a suitable hybrid can be developed that combines high leaf protein levels with desirable agronomic performance by traditional breeding practices. If only one or two individual proteins were elevated in concentration, this problem would probably be amendable to modern genetic engineering. However, chromatographic and electrophoretic evidence ver-
Figure 9.

Graph showing concentration/recovery parameters during ultrafiltration of clarified tobacco leaf extract with a Romicon hollow-fiber membrane system. Concentration factor (CF) is the ratio of the original volume to the concentrate volume where $\mathrm{CF}=$ $\frac{1}{1-R}$. Recovery index is the ratio of permeate volume to original volume where $R=\frac{V \text { permeate }}{\text { V original }}$.

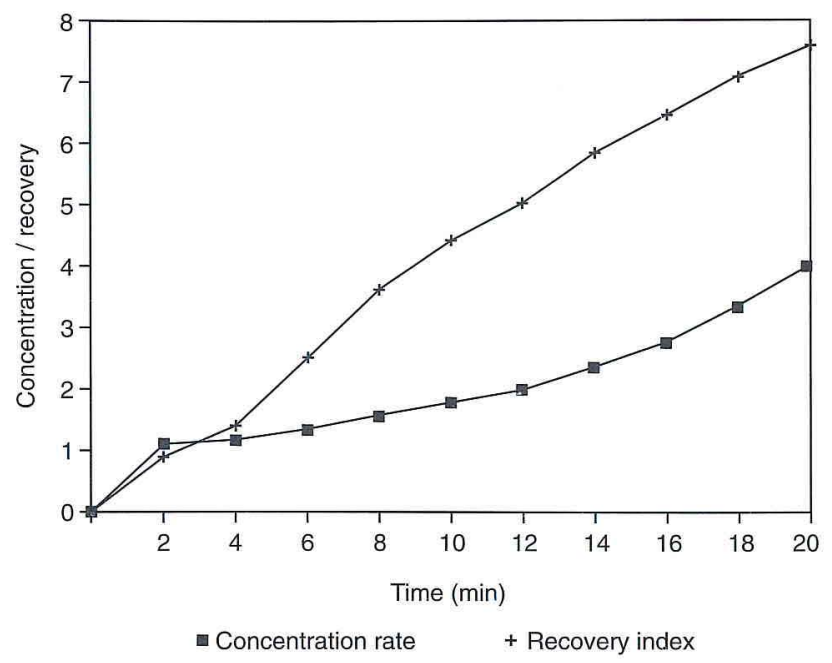

ifies that all the major groups of proteins are at unusually high concentrations in T. I. 401 leaf extracts. This suggests that the protein metabolizing machinery as a whole is involved in the phenomenon. Whether this situation is due to a high rate of synthesis or a low rate of catabolism has not been established but would be an interesting matter to investigate.

In addition to identifying an exceptionally good leaf protein producing tobacco genotype, two methods for improving the fractionation process have been demonstrated. The first of these is the combined use of mild acidification and moderate heat to destabilize the green fraction so that it can be easily removed. This procedure not only facilitated an extensive screening program but it also appears to be an excellent innovation for large scale leaf protein technology. Simultaneous concentration and purification of protein extracts by ultrafiltration has been a common laboratory practice for many years. However, various types of ultrafiltration apparatus that we have tried in the past have been disappointing because of their low capacity due to rapid membrane fouling. Performance of the Romicon system was extremely satisfactory and represented a significant improvement upon other types previously examined for this purpose. The hollowfiber membrane in the Romicon device does not cause shear and consequent protein degradation nor does it appear to be plagued by surface plugging which is a common problem with membrane systems utilized for protein filtration. The advantages of applying ultrafiltration prior to the final protein precipitation step are that it greatly reduces the load on the centrifuge while simultaneously improving the protein purity. Typical values of $60 \%$ to $80 \%$ protein in heat fractionated precipitates of clarified extracts were previously reported (3). In the 
present work, diafiltration increased this figure to over $93 \%$ protein.

In a comprehensive report to the U.S. Office of Technology Assessment, WILDMAN (9) envisioned how a practical tobacco leaf protein process might be structured. He did not, however, offer a solution to the problem of leaf protein variability under field conditions. The present authors have demonstrated that this problem of protein instability can be solved by genetic means. Furthermore, Wildman's process required the use of high speed centrifugation for protein fractionation. Such a requirement would be expensive and impractical for large-scale factory type operations. Results of the present study show that if the green fraction is suitably destabilized by a combination of $\mathrm{pH}$ adjustment and mild heat treatment, it can easily be removed by low centrifugal force without jeopardizing recovery of the soluble protein fraction. Although considerable attention has been given to the benefits of recovering a discrete Fraction I protein in crystalline form (10), it has not been proved that this advantage is worth the added expense required for fractionation. Several investigations $(10,11)$ have emphasized the favorable nutritional aspects of tobacco leaf protein. SHeEn and SheEn (12) demonstrated that, aside from the issue of nutrition, tobacco leaf protein exhibits a number of desirable functional food properties. The principal requirement is that the protein be obtained in a sufficiently pure state. As shown in this paper, ultrafiltration of the soluble protein extract prior to precipitation provides a highly concentrated protein preparation.

\section{REFERENCES}

1. Chaplin, J. F., J. R. Stavely, C. C. Litton and G. W. Pittarelli: Catalog of the Tobacco Introductions in the USDA's tobacco germplasm collection (N. tabacum); USDA/ARS Agricultural Reviews and Manuals S-27, 1982.

2. Sisson, C. A. and J. A. Saunders: Tobacco Germplasm Collection: Suppl. 1. Alkaloid content of the cured leaf; USDA/ARS Agricultural Reviews and Manuals S-27, 1983.

3. De Jong, D. W.: Tobacco leaf protein: I. An evaluation of the use of putative chemical growth enhancers for tobacco leaf protein production; Beitr. Tabakforsch. Int. 15 (1991) 33-41.

4. Bradford, M. M.: A rapid and sensitive method for the quantitation of microgram quantities of protein utilizing the principle of protein dye binding; Anal. Biochem. 72 (1976) 248-254.
5. Kawashima, N. and S. G. Wildman: Fraction I Protein; Annual Rev. of Plant Physiol. 21 (1970) 325-358.

6. De Jong, D. W. and J. A. Saunders: Fluctuations in protein levels of tobacco leaves and consequences for extractability; Beitr. Tabakforsch. Int. 13 (1986) 139-149.

7. Laemmli, U. K.: Cleavage of structural proteins during assembly of the head of bacteriophage T4; Nature 227 (1970) 680-685.

8. Sheen, S. J.: Biomass and chemical composition of tobacco plants under high density growth. Beitr. Tabakforsch. Int. 12 (1983) 35-42.

9. Wildman, S.: An alternative use for tobacco agriculture: proteins for food plus a safer smoking material. Plants - the potentials for extracting protein, medicines, and other chemicals; OTA (1983) 63-67.

10. Wildman, S. G., P. Kwanyuan and B. H. Ershoff: Production and biological evaluation of crystalline Fraction 1 Protein from tobacco leaves. Proceedings of the Conference on Nonconventional Proteins and Foods; National Science Foundation (1977) 165-171.

11. Kung, S. D., J. A. Saunders, T. C. Tso, D. A. Vaughan, M. Womack, R. C. Staples and G. Beecher: Tobacco as a potential food source and smoke material Nutritional evaluation of tobacco leaf protein; J. Food Sci. 45 (1980) 320-327.

12. Sheen, S. J. and V. L. Sheen: Functional properties of fraction 1 protein from tobacco leaf. J. Agric. Food Chem. 33 (1985) 79-83.

\section{Acknowledgements}

The authors gratefully acknowledge the expert technical assistance of Samuel Garrett, Denise Ardolini, and Brian Anderson during the course of these investigations.

\section{Authors' address:}

Crops Research Laboratory, U.S. Department of Agriculture, Agricultural Research Service, Oxford, North Carolina, 27565, U.S.A. 